\title{
Literature Review about the Influence Factors of Self-Employment
}

\author{
Lingya Wan \\ Jinan University, Guangzhou, China \\ Email: wanly_jn@163.com
}

How to cite this paper: Wan, L.Y. (2017) Literature Review about the Influence Factors of Self-Employment. American Journal of Industrial and Business Management, 7 , 79-92.

https://doi.org/10.4236/ajibm.2017.72007

Received: December 29, 2016

Accepted: February 18, 2017

Published: February 21, 2017

Copyright $\odot 2017$ by author and Scientific Research Publishing Inc. This work is licensed under the Creative Commons Attribution International License (CC BY 4.0).

http://creativecommons.org/licenses/by/4.0/

\section{(c) (i) Open Access}

\begin{abstract}
The laborer's employment form can be subdivided into wage-employment, self-employment and unemployment. Self-employment can also be called entrepreneurship, in response to the statement "Public entrepreneurship, Peoples innovation" put forward by the prime minister Li Keqiang. In recent years, self-employment has been attracting more and more attention of researchers, and becomes the research hot spot problem. Self-employment plays an important role in reducing poverty, fostering innovation, developing entrepreneurial economy, promoting economic growth, expanding employment, improving the quality of employment, cultural exchange, taxation and self-efficacy. This paper first analyzes the current situation of self-employment, and then summarizes the significance of self-employment by searching relevant literatures. At the same time, it reviews the relevant literatures at home and abroad, summarizes the research on influential factors of self-employment. The status of self-employment clarifies the factors affecting self-employment. Finally, it points out the shortcomings of the current study, and looks forward to the future trend of research.
\end{abstract}

\section{Keywords}

Self-Employment, Innovative, Employment

\section{Introduction}

Li Keqiang, prime minister, in the government work report in 2015: "Public entrepreneurship, Peoples innovation", emphasized promoting the entrepreneurship. People's innovation stimulating million people's wisdom and creativity, is the important way to make country strong and the people rich. Employment is the root of people's livelihood and the source of harmony. At present, our country is still at the primary stage of socialism and still exists a lot of social problems, especially the problem of employment. According to the relevant data, China has 
about 15 million new entrants into the labor market every year. In 2015, there were about 10 million unemployed people; at the same time, there were structural contradictions between employment difficulties. In the case of employment difficulties, encouraging the working people to start their own businesses with self-employed instead of employment, to solve the current employment pressure is of great significance. The research has shown that self-employment is of great significance to bear huge employment pressure in the development of economy; it can not only increase the income of the self-employment, but also can generate positive externalities through job creation and aggregate demand [1].

Based on the above background, self-employment activities not only got the attention of policy makers, also brought to the attention of the academic research. Part of the reason boils down to self-employment rapid growth in both developed and developing countries, for example, China nutrition and health survey data show that in the 20 years from 1989 to 2009, self-employed rate of annual growth rate is more than $10 \%$. The main reason is that the development of the self-employment to solve the employment problem, cultivate the spirit of innovation and economic growth has the vital significance. In fact, many countries have developed policies to support self-employment, such as giving the unemployed groups start-up funds, giving preferential taxation policies, etc.

This paper summarizes the domestic and foreign researchers' literatures on the influencing factors of self-employment from the selection of self-employment to the final exit. It summarizes the influence factors of choosing and withdrawing self-employment, sums up the current status of self-employment research, clarifies the main factors affecting self-employment and puts forward some suggestions. Finally, the shortcomings of the current research are pointed out, and the trend of future research is forecasted.

\section{The Definition and Significance of Self-Employment}

\subsection{What Is Self-Employment?}

Clear definition of the academic is not unified; most studies have used for the organization for economic cooperation and development (OCED), the international labor organization (ILO) and the United Nations (UN) definition of selfemployment, in particular including employees and self-employment workers. Self-employment refers to incumbents to individual business decision and shall be responsible for the welfare of the enterprise, its profit from the profit of venture enterprises (OECD, 2002). Countries machine labor organization and the United Nations, the employment statuses, unpaid family helper for employee, employer (employ one or more employees) and individual operators (not to hire any employees) four categories, and after two types of employment classified as self-employment. According to the above two definitions, the self-employment defined in this article is one of three kinds of employment-employment, unemployment and self-employment. It is an employment status, which refers to those who get some or all of their income through their own labor, Rather than selling 
their own labor to employers to obtain wage employment activities, is a result of employment choices.

\subsection{The Significance of Self-Employment}

Researchers believe that self-employment has become an individual industrial and commercial households to resolve the employment and reemployment of an important way, can promote the development of the third industry and rationalization of industrial structure, is advantageous to the formation, middle class is conducive to the construction of a harmonious society. The author thinks that, self-employment is the less developed areas in China one of the ideal path of rural labor transfer employment, to solve the inequality of the development of our country, increasing regional gap between rich and poor is of great significance. In general, self-employment plays an important role in reducing poverty, nurturing innovation, developing entrepreneurial economy, promoting economic growth, expanding employment, improving the quality of employment, cultural exchange, taxation and self-efficacy.

\section{The Influence Factors of Choosing Self-Employment}

Why do Employees choose self-employment? From an economic point of view, self-employment business can give workers more personal utility. The higher the self-employment effect, the greater the possibility of self-employment. Relative advantage hypothesis [2] [3] argues that if self-employment business utility is higher than the utility of wage employment or unemployment, individuals will choose to self-employment business. Early some scholars research thinks, when workers are not received by the formal economy and labour markets, self-employment, entrepreneurial can avoid formal labor market exclusion and discrimination, increase employment opportunities [4].

Comprehensive studies have shown that the factors affecting selection and exit self-employment related to all aspects. According to different levels, the influencing factors mainly include individual characteristics, family characteristics and social characteristics. Individual characteristics include household characteristics, health status, marital status, educational attainment, age, and gender. Family characteristics include marriage, the number of infants and young children, parental occupation. Social characteristics include unemployment rate, social culture, policy support, regional environment and so on.

\subsection{The Current Research Status of Foreign Scholars}

In recent years, foreign scholars have made a great deal of research on the influencing factors of self-employment behavior decision-making from personal characteristics, family characteristics and social characteristics, and formed a wealth of research results.

\subsubsection{Personal Characteristics}

Some scholars regard education for self-employment into the role, but in fact education influence on self-employment have covered almost contradictory two 
aspects, on the one hand, the higher the degree of individual education, the strength of its management ability, self-employment tendency will increase; on the other hand, the higher degree of education, the higher the wage income, it's expected that self-employment opportunity cost is higher, to reduce the expected utility of net, it will reduce the probability of self-employment choice, therefore, education degree influence on self-employment activity direction is uncertain [5]. By 2006, according to a survey data, study education of rural labor force selfemployment have a positive impact [6], while Lazear also found that people who have multiple jobs and education background than people who work in the single or professional are more likely to become entrepreneurs themselves [7], Borjas study found that high degree of education of the individual than the low degree of education of individuals are more likely to enter self-employment activities [8].

In terms of age, in a self-employment activity, those who experienced or relative elder age than those who are self-employment experience fewer young people are more likely to choose self-employment activities or its self-employment duration is longer, the possible reasons is that the self-employment is an activity with a logo of entrepreneurship, continuous investment, human capital and social capital to the self-employment have higher requirements, the young man is hard to get in a short time. But in theory, the effects of age on self-employment choice also has two aspects, on the one hand, the growth of the age for the more entrepreneurial experience accumulation, is more conducive to self-employment activities; the increase of age, on the other hand, the general risk preference is lower, engaged in self-employment proportion will decline. Kidd are analyzed, the structure that is more likely to be nonlinear relationship between age and the self-employment, into the age of the self-employment peak between the ages of 35 to 44 [9]. With previous year employment as explanatory variables, got similar results. He found that age, before the labour market experience, even the family composition related to the possibility of immigration self-employment [10].

Different gender for self-employment activities into the choice of is a different arrangement, for sex, usually believes that men and women are usually different factors and mechanism driven into self-employment department. Men are more likely than women to enter the high technical content of self-employment sector; women especially married women are more likely to enter the low-tech department; and women enter self-employment can consider more aspects than men, women may consider the factor of family is more, while men are mainly considering employment pay more. Boden confirmed that gender, individual choice self-employment women (especially for women with children) in order to schedule the flexibility and family are more likely to choose a self-employment [11]. Kuhn \& Schuetze studies have shown that men and women choose the reason is that there are differences of self-employment, women do not like men, is caused by deterioration of labor market conditions [12]. Hundley analyses the causes of men and women choose self-employment labor difference, analysis shows that, 
compared with the organization employees, self-employment people have more freedom to labor income and family planning according to the market demand change adjustment work hard, women's income as a self-employment person in marriage, family size and family labor time decreases, while men self-employment person income rise with marriage, family scale, the former choice of selfemployment is for the convenience of family planning, while the latter in pursuit of higher yields [13].

\subsubsection{Family Characteristics}

Marital status and the number of children's choice of self-employment play an important role. From the aspects of marriage, married immigrants relative to single individuals, not easily get slack off work, will work hard for family income maximization goal, it is easier to enter self-employment venture [14]. Blumberg and Gerard's study also found that married people relative to unmarried, family emotional help and support, more and more likely to choose self-employment venture [15]. While for have a child, the effect is not clear, on the one hand, a self-employment activity time is free, easy to care for children; but on the other hand, income also has the risk of instability, not conducive to raising children. For example Taniguchi study, number of children ( $<6$ years of age), the number of children do not accelerate women to become self-employment, larger children ( $>6$ years old children) significantly affect the white women to become self-employment, but this trend can be observed in the payroll employment [16].

For parents, if parents are self-employment, they will give the enterprise management method, management experience, business social network and reputation (reputation) passed on to the next generation of entrepreneurs' human capital and ability of intergenerational transmission can raise offspring to enter selfemployment may, extend the self-employment duration, can expect parents career for the self-employment, with their offspring are more likely to enter the self-employment business. Such as Dunn \& Holtz, Blanch flower found that if the father is a self-employment, the individual will be more likely to enter selfemployment [17] [18]. Cooper empirical research also suggests that a self-employment person parents if management enterprises, self-employment person will prolong survival period [19].

Assets increase, the probability of self-employment also improved obviously. Holtz-Eakin claimed that get heritage or lottery individuals are more likely to enter self-employment, and self-employment performance is more successful [20]. Parker stressed the importance of liquidity constraints of self-employment into decision-making role [21]. Laborer to choose self-employment probability increases with the increase of household assets. Taylor uses unexpected wealth of laborers choose self-employment indirectly proves that the influence of the selfemployment person face liquidity constraints of economics to explain, and further points out that this unexpected wealth not only affect workers choose selfemployment, and it also affect the duration of the self-employment laborer and the growth of entrepreneurial activity [22]. Transition countries in the relationship between the assets and self-employment performance is not at all, such as 
transition countries of eastern Europe's empirical shows that assets increase will reduce the probability that self-employment to enter [23].

\subsubsection{Social Characteristics}

For macro environment, some study to unemployment proxy variable to further examine the region's macro environment in different parts of the self-employment. The economic downturns, the economy's unemployment rate increase, the wage salary into the more difficult, immigrants who are willing to choose employment have to choose self-employment [24]. At the same time, the unfair economic environment will also have an effect on the choice of the selfemployment. Song's study shows that due to the division of urban and rural labor market, rural migrant workers in cities and towns is limited by the labor market and lack of employment opportunities is the main reason for the migrant workers are self-employment [25]. Arias and Khamis, labor market segmentation and discrimination of have left they were forced to choose self-employment [26]. Think employment choices reflect personal preference to work (such as the time preferences of flexible obtain employment, want to be your own boss, the value associated with social protection, medical insurance, unemployment insurance and pension insurance, etc.), into a department of constraint (lack of capital, relationship, etc.) and do not obey the cost of government regulation (punishment, social reputation, etc.). Djankov analysis of the formation of entrepreneurs from three dimensions: economic, political and legal systems on the cultivation of the entrepreneurs or limit, social relations factors shaping of entrepreneurs and entrepreneur's personal factors [27]. They found that the control system of the environmental factors, China's entrepreneurs are more likely to have family members working in the field of entrepreneurship and the childhood friends, that the social environment for entrepreneurs plays an important role. Munoz \& Cueto study showed that GDP growth to shift from salary to hire people had no effect on the duration of the self-employment individuals [28]. Fertala were included in the analysis of population density and the number of foreigners, the empirical results show that the influence of the number of foreigners to self-employment duration is an inverted $\mathrm{u}$-shaped, while the population density of self-employment duration had a positive effect [29]. A self-employment person on the tax burden is much lighter than employee wages, so for the self-employment tax breaks for workers choose to enter self-employment [30].

\subsection{The Current Research Status of Domestic Scholars}

From the search of the literature, we can see that the research on self-employment is a little lacking in China, and more attention is paid to the analysis of individual factors. Due to the special dual structure of urban and rural areas, employment of migrant workers, especially the employment of migrant workers has been a lot of constraints, so domestic scholars with the characteristics of China and foreign research is different. 


\subsubsection{Personal Characteristics}

From the domestic literatures on the above, domestic scholars more attaches great importance to the study of education for self-employment. Peng-Fei Luo, for example, empirical analysis conclusion, the low cultural level of individual not tend to be engaged in self-employment, and the possibility of high cultural degree of personal engaged in self-employment is larger [31]. But the relationship may not be linear, most tend to engage in self-employment individuals with a high school education, and graduate student is almost impossible to engage in self-employment. Jie e using CHNS data analysis found that the higher education in the absence of the hireling self-employment to have hirelings self-employment work has played a significant role in job creation [32]. Zhi-Ling Huang in the analysis of the reason for the difference between the urban and rural residents choose to hire themselves found that affected by the degree of education, the higher the education degree to choose the less likely the self-employment, but with party membership can also promote urban and rural residents choose to wage employment [33]. In China's rural migrant labor employment choice and the analysis of the income gap in the study, through empirical found to have higher education are more likely to work in the wage levels of immigration, especially long-term salary job. Good grades in school students are unlikely to choose self-employment in the future, but not decisive [34]. Also, get training can also reduce the probability of self-employment; increase the likelihood of the work in the salary for a long time. Shi Dan xi resembles, Wu Keming analysis of the influence of education on promoting self-employment laborer, he will be self-employment divided into necessity self-employment and entrepreneurial self-employment, structure shows that laborer by the lower education level, the more likely to choose necessity self-employment, college degree or above on laborer choice stimulates entrepreneurial self-employment, have opposite effects on necessity self-employment, the overall effect of higher education to self-employment laborer choice is negative [35].

Gender aspects, compared with foreign scholars, the domestic scholars mainly the different gender of hired workers consider themselves different reasons. Liu Yan, Yue-Yun Li on the employment situation of migrant rural labor in Nanjing city, on the basis of the questionnaire survey to establish a Probit model to study urban migrant rural labor sex differences in informal employment and the influencing factors of informal employment choice and the different gender impact of informal employment in rural labor force [36]. Research shows that women with age, due to the housework, give attention to two or more things undertake the obligation to raise and support, and more likely to choose flexible freedom of informal employment; older women are often cultural level is generally low, and the lack of certain skills, it also makes them difficult to engage in high threshold of normal work. However, the influence of the size of the age for men to choose self-employment is not significant. Women rely on geography, kinship in search of work makes it more likely to be informal workers, according to the survey, and a large number of women assist spouses and family members engaged in individual vendors. Family custody to outside the influence of in- 
formal employment in rural women is positive. Women with high family dependency rates are more likely to become informal workers than women with low family dependency rates, which have negative effects on informal employment in rural males. Shi Dan Xi resembles, Wu Keming studies have shown that self-employment tend to be stronger men [35]. Liu Yun calm Wang Cui e in the study of migrant workers self-employment decision mechanism of gender differences in the use CLHLS data analysis of the migrant workers in 2005 selfemployment decision mechanism of gender differences, the results show that the self department of employment and wage income gap is an important factor in promoting migrant workers choose to hire themselves, and the influence on men than women, moreover, family responsibility can affect both men and women, but the impact mechanism is different, because women especially children to take care of the family choose self-employment, men, because life stress and choose self-employment [37].

Work experience perspective, research Peng-Fei Luo, working years and correlation between individual self-employment tendency, but the correlation is not linear, 30 to 39 years old age group most tend to be engaged in the self-employment, and 15 - 29, 50 to 59, and aged 60 and above paragraph are less prone to engage in self-employment [31]. Shi Dan Xi resembles, Wu Keming (2015) also similar conclusion, choice of laborers working years self-employment with inverted u-shaped [35].

\subsubsection{Family Characteristics}

Marriage and custody, Shi Dan Xi resembles, Wu Keming studies have shown that male self-employment tend to be stronger, marriage can help workers to choose self-employment, children under the age of six workers choose self-employment probability is higher, household wealth as the proxy variable of the liquidity constraints, to choose a self-employment workers [35].

Parents occupation, Jie e using CHNS data analysis found that intergenerational transfer of human capital among the self-employment into effect significantly, compared with wage employers, the unemployed are more likely to enter self-employment activities [32]. Also found that age and gender variables have an impact on unemployment to self-employment only, but the impact is not obvious.

Discrimination factor, domestic urban and rural dual structure, the existence of the household registration system has brought China employed, self-employment choice cannot be ignored, the influence of which on the other hand, there are many scholars studied for this problem. Such as Xian-Guo Yao, ZhiLing Huang, using the data of enterprise employees in Zhejiang province about the impact of human capital for urban and rural household register discrimination results show that $80 \%$ of the wage gap is caused by individual character difference, while the other $20 \%$ is caused by discrimination [38]. Zhi-Ling Huang using CHIP2007 years data to investigate the labor market of urban and rural workers in cities and towns in self-employment problem of income gap. Structure found that self-employment income measures, with the hour town worker's income is 15.04 yuan, far higher than the migrant workers of 7.09 yuan; Form 
the self-employment income difference factors can be divided into two categories, one is the individual resources endowment difference, secondly, the household register discrimination against migrant workers [33]. Zhi-Ling Huang (2014) engaged in self-employment income than earners, but human capital returns to engage in self-employment winner under salary. Predict the winners of self-employment and wage income gap had important effect on self-employment behavior decision-making for migrant workers, the logarithmic form of the income gap and increase per unit, the self-employment probability of migrant workers increased by $87 \%$, that is in the payroll department will make the migrant workers were forced to choose self-employment employment form [39].

\subsubsection{Social Characteristics}

Characteristics of social factors, Cai-Rong $\mathrm{Wu}$, Wu Sheng Grace, the study found that the rural mercantilist grows culture and family culture, the easier the region's rural labor choose self-employment [40]; family population, the more self-employment behavior of rural labor force, the more likely. Wen-Chao Fang, Peng-Fei Luo discusses the conversion of self-employment model change during the period of institutional transition, from redistribution in China's economy to a market economy transition, and the elite, private business owners class under the market economic system has a natural close contact from hiring class is how to shape in the social stratification system [31]. Emphasized with the development of industrialization, in China under the background of system transformation, the continuous improvement of the market system, individuals will accord the characteristics of the human capital itself and preference to carry on the rational choice, to determine their own career. Xiang-Dong Wan into the conditions and effects of informal employment, found that informal employment by the human capital situation, and information to obtain the influence of such factors as wealth level [41].

\section{Research on Self-Employment Exit Decision}

Some self-employment person engaged in the self-employment, the longer the more willing to continue to maintain the working state and some of the selfemployment person find themselves not suitable for self-employment, and thus choose to quit. Rational conditions for self-employment workers are self-employment utility is lower than the wages of the utility of employment or unemployment, the difference of utility is often self-employment entrepreneur individual factors and other factors combined action result.

\subsection{Foreign Scholars' Research on Self-Employee Exit Decision}

Education for self-employment has two directions, the influence of the higher level of education could promote the workers out of self-employment, and this is because the employees choose self-employment opportunity cost is relatively high. For example Nziramasanga and Lee, the study found that the workers by education degree has a negative effect on self-employment duration, the higher the level of education, self-employment person easier to exit the self-employ- 
ment [42], but Kangasharju and Pekkala empirical studies are different conclusions, although a higher education level self-employment individuals in higher survival at the recession, but in good times easier to exit from the self-employment business, to pay hire [43]. From self-employment person gender and age, the youngest of the individual are relatively easy to exit from the self-employment, often less than men, women of self-employment duration relative to men are more likely to exit the self-employment business [44]. As a self-employment activity from start to health operations over a period of time, health and selfemployment activities operation also need certain self-employment experience to support, so the fixed number of year of the self-employment to self-employment exit behavior has a negative impact [45] [46]. Munoz and Cue to found that for the further study of the self-employment entrepreneurs to the fixed number of year of the self-employment and exit the probability of a negative relationship is not linear, self-employment person at the beginning of the self-employment business exit probability is bigger than the late indeed, but once upon a time three years, the probability of the first year out of self-employment to less than the second and third year, with the extension of time, the probability of exit to gradually become smaller [28].

Parents occupation, if self-employment person's parents work in the self-employment, parents will put the enterprise management method, management experience, business social network, such as passed on to the next generation, the intergenerational transfer will prolong the self-employment individuals, reducing the probability of self-employment exit, but also some scholars use the empirical analysis are inconsistent conclusions. Georgellis study found that parents' background and self-employment person there is no inevitable relation between the lifetimes of family factors on the self-employment person out of the effect is not significant behavior [47]. On the analysis of the macro environment factors impact of self-employment exit behaviors, Nziramasanga found that import growth, loan interest rate increase has a negative effect on self-employment survival, but the added value of industrial products has positive effect to selfemployment survival [42]. Dirk argue that the unemployment rate has a dual effect on the self-employment, on the one hand, the unemployment rate increase will force more unemployed individuals engaged in the self-employment, on the other hand, the deteriorating economic environment will make a self-employment activity is unsustainable and force the self-employment entrepreneurs to opt out of self-employment [48]. Other factors, such as Jose's (2010) study found before entering the self-employment working status for unemployment has a negative effect on self-employment survival [49].

\subsection{Domestic Scholars' Research on Self-Employee Exit Decision}

Domestic scholars study of self-employment exit behavior is less, such as Yuxiang Jie using CHNS survey data analysis of the influence factors of self-employment activity exit in our country, the duration of the studies China's nonagricultural self-employment activity, analyzed the factors affecting China self- 
employment activity exit decision [50]. Self-employment exit path is divided into two kinds, exit to wage employment and exit into unemployment, discrete time risk model and competition risk model results show that the exit into the forecast probability of unemployment than exit into high salary employment; demographic characteristics and family background have different effects on different exit path; enter self-employment from unemployment will decrease the number of self-employment exit to pay the probability of employment; self-employment time has a negative effect to self-employment exit; the proportion of the tertiary industry to GDP increase can increase the risk of self-employment exit.

\section{The Insufficiency and Prospect of Existing Literature}

By comparing the above analysis of literature review both at home and abroad about the factors affecting self-employment decisions, you can see that the foreign made a full research on the influencing factors, while domestic self-employment is insufficient. Although domestic and foreign scholars are all studying self-employment impact factors, scholars are based on different research objects, involving different economies. Because of the different national conditions of our country and abroad, our country has dual urban-rural economy, urban and rural household registration system, as a laborer, our country's citizens who choose self-employment are obviously facing a more complex background. Therefore, it is very important to analyze the influence factors of the self-employment of peasant workers in China, on the basis of the results of the factors influencing the self-employment of foreign countries and the background of our country's urbanization.

At present, domestic scholars mainly focus on the microcosmic aspects of self-employment; the study of social factors is less involved, such as more analysis of the impact of personal characteristics and family characteristics of factors. However, at present, our country is in a more and more internationalized social environment, facing the complex economic situation and the social environment; the study of social characteristics is more and more necessary. In view of the above content, the future direction of the research mainly involves the expansion of the division of micro level and macro level.

1. The different psychological characteristics of different workers on the entry and exit of self-employment have any effect?

2. What is the effect of workers' circles on employment choices in an increasingly socially friendly environment?

3. With the rapid development of scientific information, the efficient use of the Internet self-employment decisions has any effect?

4. With the economy into a stable low-speed development of domestic and international economic growth situation, self-employment decision-making will have any effect?

The research on the above issues should focus on the following aspects: First, strengthen the database construction, the establishment of the official nationwide coverage of all employment groups' survey system with data statistics and 
econometric analysis of self-employment for a comprehensive scientific analysis. Second, pay attention to self-employed employment's policy support in order to play the role of self-employment on economic development and lay a solid foundation. Finally, we must pay attention to the use of economic research purposes in a comprehensive scientific research, based on the flexible use of various economic policies to promote the continuous development of China's economic society.

\section{References}

[1] Ñopo, H. and Valenzuela, P. (2007) Becoming an Entrepreneur. IZA Discussion Paper, No. 2716.

[2] Evans, D.S. and Leighton, L.S. (1989) Some Empirical Aspects of Entrepreneurship. American Economic Review, 79, 519-535.

[3] Ree, H. and Shah, A. (1986) An Empirical Analysis of Self-Employment in the U.K. Journal of Applied Econometrics, 1, 95-108. https://doi.org/10.1002/jae.3950010107

[4] Light, I. (1972) Ethnic Enterprise in America: Business and Welfare among Chinese, Japanese, and Blacks. University of California Press, Berkeley.

[5] Le, A. (1999) Empirical Studies of Self-Employment. Journal of Economic Surveys, 13, 381-416. https://doi.org/10.1111/1467-6419.00088

[6] Wu, X. (2006) Communist Cadres and Market Opportunities: Entry into Self-Employment in China, 1978-1996. Social Forces, 85, 389-411. https://doi.org/10.1353/sof.2006.0149

[7] Lazear, E. (2005) Entrepreneurship. Journal of Labor Economics, 23, 649-680. https://doi.org/10.1086/491605

[8] Borjas, G. and Bronar, S. (1986) Consumer Discrimination and Self-Employment. Journal of Political Economy, 97, 581-605. https://doi.org/10.1086/261617

[9] Kidd, P. (1993) Immigrant Wage Differential and the Role of Self-Employment in Australia. Australia Economic Papers, 32, 92-115. https://doi.org/10.1111/j.1467-8454.1993.tb00133.x

[10] Lofstrom, M. (2000) Self-Employment and Earnings among High-Skilled Immigrants in the United States. CCIS Working Paper, University of California, San Diego.

[11] Boden, R. (1999) Flexible Working Hours, Family Responsibilities, and Female SelfEmployment: Gender Difference Selection. American Journal of Economic and Sociology, 58, 71-83. https://doi.org/10.1111/j.1536-7150.1999.tb03285.x

[12] Kunhn, P. and Schuetze, H. (2001) Self-Employment Dynamics and Self-Employment Trends: A Study of Canadian Men and Women, 1982-1998. Canadian Journal of Economics, 34, 760-784. https://doi.org/10.1111/0008-4085.00098

[13] Hundley, G. (2000) Male-Female Earning Differences in Self-Employment. Industrial and Labor Relations Review, 54, 95-114. https://doi.org/10.1177/001979390005400106

[14] Borjas, G.J. (1986) The Self-Employment Experience of Immigrants. Journal of Labor Economics, 16, 26-60. https://doi.org/10.3386/w1942

[15] Boris, B. and Pfann, G. (2001) Social Capital and the Uncertainty Reduction of SelfEmployment. IZA Discussion Paper.

[16] Taniguchi, H. (2002) Determinants of Women's Entry into Self-Employment. Social Science Quarterly, 83, 876-893. 
[17] Dunn, T. and Holtz-Eakin, D. (1996) Financial Capital, Human Capital and the Transition of Self-Employment: Evidence from Intergenerational Links. NBER Working Paper Series, Working Paper 5622. https://doi.org/10.3386/w5622

[18] Blanchflower, D. and Meyer, B. (1994) A Longitudinal Analysis of Young Entrepreneurs in Australia and the United States. Small Business Economics, 6, 1-20. https://doi.org/10.1007/BF01066108

[19] Cooper, A.C., Gimeno-Gascon, F.J. and Woo, C.Y. (1994) Initial Human and Financial Capital as Predictors of New Venture Performance. Journal of Business Venturing, 9, 371-395.

[20] Holtz-Eakin, D., Joulfaian, D. and Rosen, R.H. (1994) Entrepreneurial Decision and Liquidity Constraints. Rand Journal of Economics, 25, 334-347. https://doi.org/10.2307/2555834

[21] Parker, S. (2004) The Economics of Self-Employment and Entrepreneurship. Cambridge University Press, Cambridge. https://doi.org/10.1017/CBO9780511493430

[22] Taylor, P. (2001) Self-Employment and Windfall Gains in Britain: Evidence from Panel Data. Economica, 68, 539-565. https://doi.org/10.1111/1468-0335.00261

[23] Earle, J.S. and Sakova, Z. (2000) Business Start-Ups or Disguised Unemployment? Evidence on the Character of Self-Employment from Transition Economies. Labour Economics, 7, 575-601. https://doi.org/10.1016/S0927-5371(00)00014-2

[24] Tervo, H. (2008) Self-Employment Transitions and Alternation in Finish Rural and Urban Labour Markets. Paper in Regional Science, 187, 55-76. https://doi.org/10.1111/j.1435-5957.2007.00150.x

[25] Song, L. and Appleton, S. (2008) Social Protection and Migration in China: What Can Protect Migrants from Economic Uncertainty? IZA Discussion Paper, No. 3594.

[26] Arias, O. and Khamis, M. (2008) Comparative Advantage, Segmentation and Informal Earnings: A Marginal Treatment Effects Approach. IZA Discussion Paper, No. 3916.

[27] Djankov, S., Qian, Y., Roland, G. and Zhuravskaya, E. (2006) Who Are China's Entrepreneurs? American Economic Review Papers and Proceedings, 96, 348-352. https://doi.org/10.1257/000282806777212387

[28] Munoz, F. and Cueto, B. (2008) The Sustainability of Start-Up Firm among Formerly Wage Workers. Working Paper.

[29] Fertala, N. (2008) The Shadow of Death: Do Regional Differences Matter for Firm Survival across Native and Immigrant Entrepreneurs. Empirica, 35, 59-80. https://doi.org/10.1007/s10663-007-9051-2

[30] Schuetze, H. (2002) Profiles of Tax Non-Compliance among the Self-Employment in Canada: 1969 to 1992. Canada Public Policy, 28, 219-238. https://doi.org/10.2307/3552326

[31] Luo, P. (2004) Human Capital and Social Capital Have How Individuals Tend to Engage in Self-Employed and Easier to Succeed in Self Employment. Journal of Zhejiang University.

[32] Jie, E. (2012) China's Non-Agricultural Self-Employed Activity Transform into the Analysis. Economic Research Journal, 2, 54-66.

[33] Huang, Z. (2012) Urban and Rural Household Registration Self-Employed Difference and the Reason Analysis. World Economic Papers, 6, 111-119.

[34] Ning, G. (2012) Self-Employed or Become Winner Salary?-China's Rural Migrant Labor Employment Choice and Income Differences. Management World, 7, 54-66.

[35] Shi, D. and Wu, K. (2015) Education to Promote Workers Hired Myself? Based on 
the Experience of the CHIP Data Analysis. Journal of Zhongnan University of Economics and Law, 3, 19-26.

[36] Liu, Y. and Li, Y. (2007) Informal Employment in Urban Migrant Rural Labor Analysis of Gender Difference, Taking Nanjing as an Example. Chinese Rural Economy, 12, 20-27.

[37] Liu, Y. and Wang, C. (2013) Migrant Workers Self Employment Decision Mechanism of Gender Differences. Population \& Economics, 4, 96-102.

[38] Yao, X. and Huang, Z. (2008) Human Capital and Household Register Discrimination, Based on the Research of the Data for Enterprise Employees in Zhejiang Province. Journal of Zhejiang University (Humanities and Social Sciences), 6, 57-64.

[39] Huang, Z. (2014) Human Capital, Income Inequality and Self-Employment Migrant Workers Behavior. Agricultural Economic Question, 6, 39-45.

[40] Wu, C. and Wu, S. (2012) Rural Labor Force in Less Developed Areas of Self Employment Behavior Influence Factor Analysis-The Sha County in Fujian as an Example. Technology Economics, 1, 86-90.

[41] Wan, X. (2008) Enter the Condition and Effect of Rural Migrant Workers in Informal Employment. Management World, 1, 63-74.

[42] Nziramasanga, M. and Lee, M. (2001) Duration of Self-Employment in Developing Countries: Evidence from Small Enterprises in Zimbabwe. Small Business Economics, 17, 239-253. https://doi.org/10.1023/A:1012209408597

[43] Kangasharju, A. and Pekkala, S. (2002) The Role of Education in Self-Employment Success in Finland. Growth and Change, 33, 216-237.

[44] Van Praag, C.M. (2003) Business Survival and Success of Young Small Business Owners. Small Business Economics, 21, 1-17. https://doi.org/10.1023/A:1024453200297

[45] Carrasco, R. (1999) Transitions to and from Self-Employment in Spain: An Empirical Analysis. Oxford Bulletin of Economics and Statistics, 61, 315-341. https://doi.org/10.1111/1468-0084.00132

[46] Lin, Z., Picot, G. and Compton, J. (2000) Entry and Exit Dynamics of Self-Employment in Canada. Small Business Economics, 15, 105-125. https://doi.org/10.1023/A:1008150516764

[47] Georgellis, Y., Sessions, J.G. and Tsitsianis, N. (2007) Pecuniary and Non-Pecuniary Aspects of Self-Employment Survival. Quarterly Review of Economics and Finance, 47, 94-112. https://doi.org/10.1016/j.qref.2006.03.002

[48] Oberschachtsiek, D. (2010) How Do Local Labor Market Conditions and Individual Characteristics Affect Quitting Self-Employment. Working Paper.

[49] Emilio, J.M.M., Concepcio, C. and Roma (2010) Determinants of Self-Employment Survival in Europe. Working Paper.

[50] Jie, Y. (2012) The Duration of the China's Non-Agricultural Self-Employed Activities: Based on the Single Risk and Competitive Risk Analysis of the Model. South China Journal of Economics, 11, 156-168. 
Submit or recommend next manuscript to SCIRP and we will provide best service for you:

Accepting pre-submission inquiries through Email, Facebook, LinkedIn, Twitter, etc. A wide selection of journals (inclusive of 9 subjects, more than 200 journals)

Providing 24-hour high-quality service

User-friendly online submission system

Fair and swift peer-review system

Efficient typesetting and proofreading procedure

Display of the result of downloads and visits, as well as the number of cited articles Maximum dissemination of your research work

Submit your manuscript at: http://papersubmission.scirp.org/

Or contact ajibm@scirp.org 